\title{
MANAJEMEN STRES DAN ANSIETAS WARGA DI KELURAHAN BENCONGAN INDAH TANGERANG
}

\author{
Maria Veronika Ayu Florensa, Veronica Paula, Yenni Sitanggang, \\ Shinta Yuliana Hasibuan, Mega Tri Anggraini, Adventina Situngkir \\ Universitas Pelita Harapan, Tangerang, Banten \\ maria.florensa@uph.edu, veronica.paula@uph.edu, yenni.sitanggang@uph.edu, shinta.hasibuan@uph.edu, \\ mega.anggraini@uph.edu, adventina.situngkir@uph.edu
}

\begin{abstract}
Abstrak
Latarbelakang:Kesehatan jiwa merupakan kondisi dimana seseorang dapat berkembang secara fisik, mental, spiritual serta sosial, serta mampu memberikan kontribusi bagi masyarakatnya. Individu tidak dapat bebas dari stres. Apabila stres tidak dikelola dengan baik dapat berlanjut menjadi ansietas dan masalah kesehatan jiwa lainnya. Data Riskesdas 2018 menunjukkan terjadi peningkatan jumlah penderita psikosis dari 1,7\% menjadi 7\% per mil, sedangkan penderita gangguan mental emosional meningkat dari 6 menjadi $9 \%$ per mil. Jumlah penderita depresi di provinsi Banten mencapai $8.7 \%$. Tingginya jumlah penderita gangguan jiwa dari waktu ke waktu membutuhkan tindakan promosi dan pencegahan gangguan jiwa. Tujuan: Pengabdian kepada masyarakat ini bertujuan agar warga masyarakat mampu mengenali tanda dan gejala stres dan ansietas serta dapat melakukan cara pengelolaannya. Metode: Kegiatan ini dilakukan melalui penyuluhan dan demonstrasi cara mengelola stres dan ansietas berupa teknik relaksasi napas dalam, hypnosis 5 jari, afirmasi positif dan relaksasi otot progresif. Hasil: Hasil kegiatan diukur dengan membandingkan nila pre-test dan post-test pengetahuan pasien sebelum dan sesudah dilakukan pemberian materi. Hasilnya, terdapat peningkatan pengetahuan warga terkait kesehatan, kesehatan jiwa, tanda gejala stres dan ansietas. Warga juga mampu melakukan tindakan yang diajarkan untuk mengelola stres dan ansietas. Kegiatan ini diharapkan dapat dilaksanakan secara berkelanjutan dengan bantuan para kader masyarakat.
\end{abstract}

Kata Kunci: kesehatan jiwa, stres, ansietas

\section{PENDAHULUAN}

Kesehatan jiwa merupakan salah satu bagian integral dari kesehatan secara umum. Kesehatan jiwa bukan hanya kondisi di mana seseorang terbebas dari gangguan jiwa, namun juga kondisi dimana individu memiliki kondisi emosi, psikologis dan sosial yang baik (Kementrian Kesehatan Republik Indonesia, 2014; Videbeck, 2011). Kesehatan jiwa yang baik akan berpengaruh pada produktivitas seseorang. Tidak dipungkiri, dalam kehidupan sehari-hari individu tidak dapat terbebas dari stres atau tekanan. Stres yang dikelola dengan baik dapat berdampak pada pertumbuhan pribadi yang lebih baik dan matang. Namun stres yang tidak dikelola dengan baik, dapat berpotensi menimbulkan ansietas bahkan dapat menjadi permasalahan kesehatan jiwa yang lebih serius.

Estimasi prevalensi gangguan jiwa di Eropa pada tahun 2015 mencapai 110 juta, yang mana sama seperti $12 \%$ dari populasi. Masalah kejiwaan yang terbesar di Eropa yaitu depresi (44,3 juta) dan ansietas (37.3 juta). Sedangkan, penyebab stress di negara maju salah satunya seperti di Amerika antara lain karena masa depan negara (63\%), keuangan

Kesehatan 409 
(62\%), pekerjaan (61\%), politik (57\%), serta kekerasan dan kriminalitas (51\%) (Association, 2017). Indonesia merupakan negara berkembang yang juga masih belum terlepas dari masalah kesehatan jiwa. Prevalensi gangguan jiwa berat yaitu skizofrenia yang terdata pada tahun 2018 mencapai angka 7 permil. Angka ini meningkat dari lima tahun sebelumnya yaitu 1.7 per mil. Masalah kejiwaan lainnya seperti depresi menempati angka 6 per mil pada tahun 2018. Sedangkan prevalensi penderita gangguan mental emosional menempati posisi 9.8 per mil dari lima tahun sebelumnya yang menempati 6 per mil.

Kelurahan Bencongan Indah termasuk ke dalam kecamatan Curug provinsi Banten. Jumlah penderita Depresi di provinsi Banten berdasarkan Riset Kesehatan Dasar 2018 berjumlah 8.7\%. Angka ini lebih tinggi dari rata-rata penderita depresi di Indonesia tahun 2018. Hal ini tidak jauh berbeda dengan penderita gangguan jiwa berat skizofrenia yang juga meningkat dari lima tahun sebelumnya. Melihat peningkatan angka penderita masalah kejiwaan, promosi yang berkaitan dengankesehatan jiwa sangat diperlukan. Promosi kesehatan jiwa merupakan upaya untuk meningkatkan kesehatan jiwa, memampukan individu ketika melalui situasi yang sulit dan memaksimalkan tugas perkembangan di usianya (Stuart, Keliat, \& Pasaribu, 2016).

Kesadaran masyarakat akan perlunya memelihara kesehatan jiwa menjadi hal yang perlu segera dilakukan. Upaya promosi kesehatan jiwa yang dilakukan pemerintah belum maksimal menjangkau masyarakat. Hal ini dibuktikan dengan belum adabya kader kesehatan di Kelurahan Bencongan Indah. Pelayanan kesehatan jiwa masih berfokus pada kuratif seperti rujukan pasien yang mengalami masalah kesehatan jiwa. Apabila upaya promotif dan preventif kesehatan jiwa tidak gencar dilakukan maka angka masalah kejiwaan dan gangguan jiwa dapat meningkat.

Berdasarkan latarbelakang di atas, dibuatlah pengabdian kepada masyarakat (PkM) yang bertujuan untuk memberikan pengetahuan terkait stres dan ansietas yang dapat dialami individu dalam kehidupan sehari hari, serta cara penanganan mandiri yang dapat dilakukan oleh warga.

\section{METODE}

Kegiatan PkM diawali dengan persiapan sebelum pelaksanaan yang terdiri dari melakukan perijinan kepada pihak puskesmas sekaligus kelurahan Bencongan Indah pada bulan Januari sampai dengan Februari 2019. Setelah tim mendapatkan persetujuan ijin dari puskesmas dan kelurahan bencongan, tim melakukan persamaan persepsi bersama anggota tim lainnya tentang topik penyuluhan dan metode penanganan stres dan ansietas. Selanjutnya tim melakukan sosialisasi kegiatan dan di sertai oleh pengurus RW dan kader masyarakat.

Kegiatan PkM dilakukan dengan metode penyuluhan dalam satu kali pertemuan. Sebelum penyuluhan dilaksanakan, peserta terlebih dahulu diberikan pre-test. Pre-test yang diberikan sejumlah lima pertanyaaan yang berisi pengertian kesehatan, pengertian kesehatan jiwa, gejala ansietas, gejala stres dan juga penanganan yang dilakukan dalam menangani stres. Kemudian peserta diberikan penyuluhan tentang stres dan ansietas yang meliputi: pengertian kesehatan jiwa, penyebab stres dan ansietas, serta penanganan kedua masalah tersebut. Setelah penyuluhan diberikan, tim mengajarkan metode untuk mengurangi stres dan ansietas. Adapun metode nya berupa teknik relaksasi napas dalam, afirmasi positif, relaksasi otot progresif serta hypnosis lima jari. Penyuluh pertama-tama mendemonstrasikan keempat metode tersebut diatas lalu selanjutnya penyuluh meminta peserta mengulangi dan melakukan empat metode tersebut secara bersama-sama.

\section{HASIL DAN PEMBAHASAN}

\section{Pengetahuan warga tentang stres dan ansietas}

Pelaksanaan kegiatan dihadiri oleh 50 warga kelurahan Bencongan Indah. Warga diberikan lima pertanyaan sebelum dan sesudah penyampaian materi. Pertanyaan tersebut antara lain tentang kesehatan, kesehatan jiwa, serta tanda gejala stres dan ansietas. 
Tabel 1 Pengetahuan warga tentang stres dan ansietas sebelum dan sesudah diberikan penyuluhan

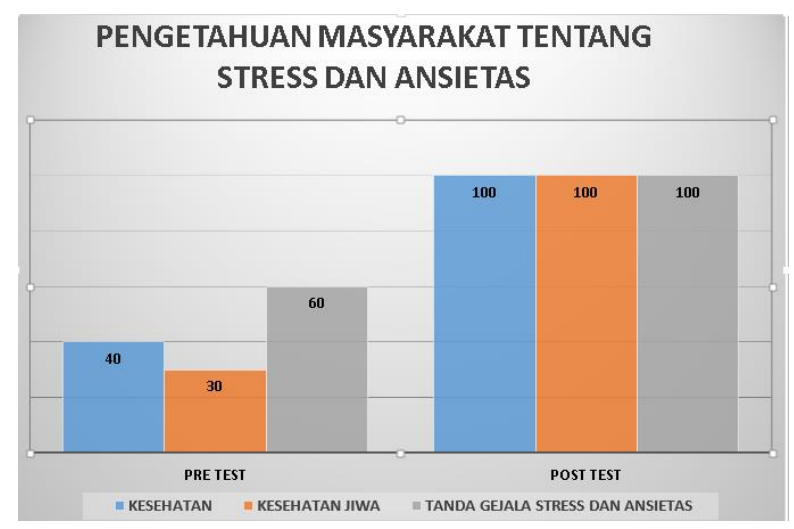

Berdasarkan Tabel 1 terdapat peningkatan pengetahuan warga yang signifikan setelah mendapatkan penyuluhan. Hal ini sesuai dengan tujuan promosi kesehatan jiwa yaitu penyuluhan yang dilakukan untuk meningkatkan kemampuan masyarakat dalam menangani masalah (Stuart, Keliat, Pasaribu, 2016). Hasil penelitian juga membuktikan bahwa penyuluhan kesehatan jiwa yang diberikan kepada masyarakat dapat meningkatkan dan memelihara kesehatan jiwa masyarakat (Florensa, Keliat, Wardani, \& Sulistyowati, 2019). Pengetahuan yang meningkat tentang kesehatan jiwa diharapkan dapat membuat masyarakat lebih peduli terhadap pemeliharaan kesehatan jiwa khususnya dalam mengelola stres dan ansietas.

Warga Bencongan Indah diberikan pertanyaan seputar pengertian kesehatan, kesehatan jiwa, serta tanda gejala stress dan ansietas. Selain itu, pengalaman warga untuk menangani stress dan ansietas juga digali. Berdasarkan jawaban warga, sebagian besar menyampaikan pemahaman yang belum mendalam terkait kesehatan jiwa. Disampaikan pula bahwa masalah yang terkait psikologis atau kejiwaan masih merupakan hal yang tabu untuk dibicarakan. Warga cenderung menghindari pembicaraan yang terkait masalah kejiwaan.
Tanda dan gejala yang dialami oleh warga terkait stres antara lain emosi menjadi mudah berubah, mudah tersinggung, sedih, enggan untuk kontak atau bertemu dengan orang lain. Berdasarkan penyebabnya, stress dapat dibedakan menjadi tiga tingkatan yaitu stress ringan, sedang dan berat. Individu yang mengalami stress ringan biasanya mengalami gejala yang tidak berdampak terhadap psikologis individu tersebut. Stres sedang terjadi lebih lama dibandingkan dengan stress ringan, dapat ditimbulkan dari beberapa jam hingga beberapa hari. Stres sedang dapat berasal dari pekerjaan sehari-hari. Stress berat merupakan level yang paling tinggi. Stress berat disebut juga stres kronis, penyebabnya dapat berasal dari hubungan keluarga yang tidak harmonis, kesulitan finansial, serta penyakit kronis. (Stuart, Keliat, Pasaribu, 2016)

Stres bisa dialami oleh setiap orang di dalam kehidupan sehari-hari dan penyebabnya sangat bervariasi. American Psychological Association (APA), 2019 melaporkan bahwa perempuan lebih cenderung memiliki tingkat stres yang meningkat dibandingkan pria. Tidak hanya itu, perempuan juga diketahui lebih cenderung melaporkan gejala fisik dan gejala emosional saat mengalami stres. Status menikah juga dilaporkan memiliki tingkat stres lebih tinggi dibandingkan individu yang tidak menikah. Penyebab stres dapat disebabkan oleh individu itu sendiri, keluarga, lingkungan atau bahkan dari pekerjaan. Se dan Anto (2014) menyebutkan bahwa pekerjaan merupakan salah satu hal yang dapat berkontribusi dalam meningkatkan stres bagi individu(Se \& Anto, 2014)(Se \& Anto, 2014)(Se \& Anto, 2014)(Se \& Anto, 2014)(Se \& Anto, 2014)(Se \& Anto, 2014)(Se \& Anto, 2014).

Pada kegiatan PkM ini, tim tidak mengidentifikasi secara khusus tingkat stres pada peserta berdasarkan jenis kelamin ataupun status pernikahan. Selanjutnya, tim juga tidak mengidentifikasi penyebab stres pada warga kelurahan Bencongan Indah, namun tim penyuluh memaparkan secara rinci hal-hal apa saja yang dapat menyebabkan seseorang mengalami stres.

Ansietas adalah perasaan cemas terhadap hal yang tidak diketahui jelas penyebabnya. Ansietas memiliki beberapa tahapan antara lain ansietas ringan, ansietas sedang, ansietas berat dan panik 
(Stuart, Keliat, Pasaribu, 2016). Pada umumnya, ansietas ringanlah yang sering dialami oleh individu di dalam kehidupan sehari-hari. Dalam hal ini, ansietas ringan tergolong baik dialami oleh seseorang, karena dapat memberikan motivasi untuk menyelesaikan target yang perlu dicapai.

Tanda gejala yang dirasakan oleh warga ketika cemas yaitu jantung berdebar-debar, sakit kepala, sampai dengan terjadi peningkatan tekanan darah. Gejala yang disampaikan oleh warga ini didukung oleh teori tentang level ansietas, yang mana terdapat empat level ansietas dengan gejalanya yang berbeda-beda mulai dari ansietas ringan, sedang, berat sampai dengan panik. Ansietas ringan merupakan ansietas yang biasanya dialami saat terjadi ketegangan hidup sehari-hari. Ansietas ringan memberikan dampak yang baik bagi seseorang karena dapat memberikan motivasi dan mencegah individu mengalami suatu masalah. Ansietas sedang timbul dari ketegangan yang lebih berat lagi. Ansietas sedang membuat individu menajdi hanya berfokus pada hal yang sangat penting saja. Ansietas sedang membuat individu menjadi kurang perhatian terhadap apa yang ia lihat dan dengar. Terdapat gejala fisik yang menyertai pada tingkatan ini seperti banyak berkeringat, merasa gelisah, mondar-mandir serta wajah tampak pucat. Tingkatran lainnya yaitu ansietas berat. Individu yang mengalami ansietas berat mengalami penurunan pada kemampuan mempersepsikan sesuatu. Ketika berada pada ansietas berat, seseorang perlu bantuan untuk dapat fokus berpikir.Tahap yang paling tinggi dari ansietas yaitu tahapan panik. Kondisi panik dikaitkan dengan rasa takut dan teror. Individu yang berada pada tahap ini tidak dapat melakukan hal apapun meskipun dengan diberikan arahan. Terjadi penurunan kemampuan dalam berhubungan dengan orang lain. Terdapat peningkatan aktivitas motorik seperti gemetar dan sebagainya. Tubuh pun memberikan respon terhadap kondisi panik ini, terjadi peningkatan tekanan darah dan tanda-tanda vital yang lainnya. (Stuart, Keliat, Pasaribu, 2019). Berdasarkan penjelasan terkait level ansietas di atas, warga Bencongan Indah kemungkinan berada pada level ansietas ringan sampai sedang. Namun pada pre test tidak diklasifikasikan level dari ansietas yang dialami oleh warga.

\section{Pengelolaan stres dan ansietas warga}

Sebelum diberikan penyuluhan warga menyampaikan bahwa hal yang dilakukan ketika menghadapi stress dan ansietas biasanya yaitu berdoa, mengalihkan dengan bercerita dengan orang yang dipercaya, namun ada juga yang memendam di dalam hati. Warga menyampaikan bahwa belum pernah diadakan penyuluhan terkait cara-cara menangani stres atau ansietas sehingga mereka menangani stres dengan cara yang mereka mampu.

Pengelolaan stres dan ansietas warga yang diajarkan yaitu teknik relaksasi napas dalam, relaksasi otot progresif, afirmasi positif dan hypnosis lima jari. Keempat cara ini dapat dilakukan secara mandiri oleh warga ketika sedang berada pada kondisi stres dan ansietas. Teknik relaksasi napas dalam efektif dalam menurunkan tingkat stres pada individu. Teknik relaksasi napas dalam juga diaplikasikan pada beberapa teknik manajemen stres seperti hipnosis 5 jari dan relaksasi otot progresif. Terdapat perubahan psiko-fisiologi pada tubuh dengan melakukan teknik relaksasi napas dalam. Teknik bernapas lambat mempengaruhi sistem saraf pusat dan otonom yang secara khusus berdampak terhadap jantung dan paru-paru (Creswell et al., 2014). Bila dikaitkan dengan tingkat stress dan ansietas, teknik relaksasi napas dalam dapat diterapkan pada stress dengan tingkatan ringan sampai sedang saja. Pada level ansietas berat dan stress berat, individu cenderung sulit memfokuskan pikiran dan mengendalikan diri sehingga akan sulit menerapkan tahapan relaksasi napas dalam. Setelah dijelaskan tentang car melakukan teknik relaksasi napas dalam, penyuluh meminta warga untuk mengulangi kembali tahapan teknik relaksasi napas dalam. Semua warga tampak mampu mempraktikkan teknik relaksasi napas dalam dengan baik sesuai dengan tahapan yang diajarkan. Teknik manajemen stress dan ansietas lainnya yang diajarkan yaitu relaksasi otot progresif.

Relaksasi otot progresif diajarkan pada warga karena dapat dilakukan secara mandiri, kapan pun dan dimanapun seseorang berada. Relaksasi otot progresif tidak memerlukan peralatan tertentu dalam pengaplikasiannya, individu hanya menggunakan dirinya sendiri. Teknik ini dilakukan dari otot wajah

$$
\text { Kesehatan }
$$


hingga otot kaki. Otot area tertentu dikontraksikan sembari individu menarik napas dalam, kemudian otot di relaksasikan bersamaan dengan napas dihembuskan melalui mulut secara perlahan. Relaksasi otot progresif telah diteliti dapat menurunkan tingkat stres pada individu (Maghfirah, Sudiana, \& Widyawati, 2015) Penelitian lainnya yang juga meneliti tentang relaksasi otot progresif memberikan hasil bahwa terdapat pengaruh yang signifikan antara pemberian terapi dengan tingkat depresi (Alfiyanti, Setyawan, Kusuma, 2014)

\section{Gambar 1 Warga mempraktikan teknik relaksasi} otot progresif.

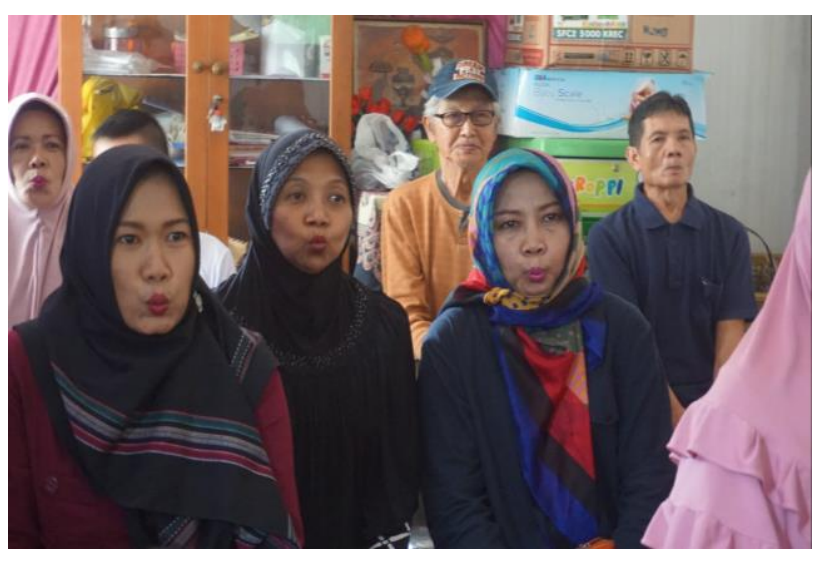

Gambar 1 memperlihatkan warga sedang mempraktikkan tahapan relaksasi otot progresif area wajah. Relaksasi otot progresif dapat dibedakan menjadi beberapa area seperti area wajah, leher, punggung, anggota gerak atas, anggota gerak bawah. Ketika mempraktikkan tahapan teknik relaksasi otot progresif warga kembali mempraktikan teknik relaksasi napas dalam.

Teknik selanjutnya yang digunakan untuk menurunkan tingkat stress dan ansietas yaitu hypnosis lima jari. Hipnosis lima jari dapat digunakan untuk menurunkan ansietas. Teknik ini membutuhkan seorang pemandu untuk mengarahkan individu dalam membayangkan hal-hal yang menyenangkan. Teknik ini baik digunakan untuk individu yang sehat maupun yang memiliki gangguan fisik dan sedang mengalami ansietas. Satu penelitian membuktikan bahwa teknik hipnosis lima jari dapat menurunkan tingkat ansietas pada pasien dengan masalah fisik baik yang baru pertama kali dirawat di rumah sakit maupun klien yang sudah pernah dirawat sebelumnya di rumah sakit (Rizkiya, PH, \& Susanti, 2017). Saat pelaksanaan hipnosis lima jari, warga yang diajarkan teknik ini dapat mengikuti arahan dari pemandu dengan baik. Saat melakukan Teknik ini, tim membuat suasana yang tenang dalam melaksanakan hipnosis lima jari ini. Warga diminta untuk menutup mata, sambal mengatur napas. Kemudian dengan dipandu oleh penyuluh, warga diminta untuk membayangkan: tempat yang paling membuatnya merasa nyaman, membayangkan bila ia berada pada kondisi tertentu dimana merasa sangat sehat, membayangkan pencapaian yang pernah ia alami sehingga ia merasa sangat bangga, serta diminta membayangkan orang yang paling berarti di dalam hidupnya. Penggunaan teknik hypnosis lima jari ini akan lebih efektif apabila dilakukan dengan kolaborasi teknik relaksasi napas dalam. Hal ini didukung oleh sebuah penelitian yang menyebutkan bahwa terdapat penurunan ansietas pada pasien dengan penyakit fisik yang diberikan treatment relaksasi napas dalam serta hypnosis lima jari (Febrina \& Malfasari, 2018)

Afirmasi positif merupakan cara terakhir yang diajarkan pada warga untuk menurunkan tingkat stres dalam kehidupan sehari-hari. Afirmasi positif merupakan cara untuk mengubah pikiran bawah sadar manusia dari pemikiran yang negatif menjadi pemikiran yang positif. Afirmasi positif yang dapat digunakan yaitu dengan mencari hal hal yang memotivasi diri. Misalnya "hari ini pekerjaan saya berjalan dengan baik", "saya berharga, saya dicintai banyak orang", "tubuh saya sehat, saya mampu melakukan banyak hal hari ini". Warga diminta untuk memikirkan kata-kata afirmasi yang sesuai dengan dirinya masing-masing.

Penelitian juga telah membuktikan bahwa didapatkan hubungan yang signifikan antara afirmasi positif dari nilai-nilai yang dianut oleh individu terhadap stres psikologis yang dihadapinya. Individu yang secara teratur melakukan afirmasi positif memiliki respon kortisol terhadap stres lebih rendah daripada individu yang tidak melakukan afirmasi positif. Afirmasi positif merupakan cara yang sangat 
efisien karena tidak menggunakan peralatan apapun dan hanya menggunakan diri sendiri. Dibutuhkan konsistensi warga dalam melatih untuk melakukan setiap manajemen stres yang diajarkan. Latihan manajemen stres dan ansietas yang dilakukan setiap hari membuat seseorang lebih terbiasa menggunakan teknik tersebut ketika sedang menghadapi kondisi stres (Creswell et al., 2014).

Manajemen stres merupakan salah satu perilaku positif yang bila terus menerus diulangi penggunaannya akan membentuk sebuah kebiasaan. Hal ini sejalan dengan teori perilaku yang menyebutkan bahwa perubahan perilaku dapat menjadi suatu perubahan yang stabil bila dilakukan terus menerus, dan dibutuhkan waktu sekitar minimal enam bulan untuk membuat suatu perilaku dilakukan dengan kesadaran sendiri oleh individu (Stuart, Keliat, pasaribu, 2016).

\section{KESIMPULAN}

Kegiatan pengabdian kepada masyarakat yang berbentuk penyuluhan manajemen stres dan ansietas warga di Kelurahan Bencongan Indah Tangerang ini berhasil memberikan dampak berupa peningkatan pengetahuan warga terkait kesehatan jiwa, stres, ansietas serta cara penanganan stres dan ansietas oleh warga. Manajemen stres dan ansietas warga yang telah diajarkan berupa teknik relaksasi napas dalam, relaksasi otot progresif, hipnosis lima jari serta afirmasi positif. Beberapa teknik manajemen stres dan ansietas yang diajarkan ini tetap membutuhkan partisipasi setiap warga untuk konsisten melatih pelaksanaannya secara pribadi. Diharapkan warga dapat menangani stres dan ansietas sehari hari secara mandiri sehingga tercipta masyarakat yang sehat jiwa.

\section{UCAPAN TERIMAKASIH}

Terima kasih dan apresiasi kami sampaikan kepada Kelurahan Bencongan Indah, perangkat RW dan RT, Ibu-Ibu Kader Posyandu dan Posbindu, pihak Puskesmas Jalan Kutai ,serta warga masyarakat Bencongan Indah Tangerang yang telah berpartisipasi dalam pengabdian masyarakat berupa manajemen stres dan ansietas warga.

Terima kasih juga kami sampaikan pada pihak LPPM UPH yang telah memberikan kami kesempatan untuk melaksanakan kegiatan pengabdian masayakat yang merupakan salah satu upaya promosi kesehatan jiwa di masyarakat ini (Nomor PkM PM-051/FoN/I/2019).

\section{REFERENSI}

American Psychological Association. (2019). Gender and stres. Retrieved from https://www.apa.org/news/press/releases/stres/ 2010/gender-stres

Alfiyanti,Nur Eva.,Setyawan, Dodi., Kusuma ,Muslim Argo Bayu. (2014). Pengaruh Relaksasi otot Progresif terhadap Tingkat Depresi pada pasien gagal ginjal kronik yang Menjalani Hemodialisa di RS Telogorejo Semarang.Karya ilmiah http://ejournal.stikestelogorejo.ac.id/index.php /ilmukeperawatan/article/view/278

Association, A. P. (2017). STRESS IN AMERICA TM : THE STATE OF OUR NATION. In book (pp. 1-6).

Creswell, J. D., Welch, W. T., Taylor, S. E., Sherman, D. K., Gruenewald, T. L., Mann, T., ... Mann, T. (2014). Affirmation of Personal Values Buffers Neuroendocrine and Psychological Stress Responses. https://doi.org/10.1111/j.14679280.2005.01624.x

Febrina, R., \& Malfasari, E. (2018). Efek terapi relaksasi nafas dalam dan hipnosis 5 jari terhadap penurunan ansietas pasien heart failure, 4, 250-260.

Florensa, M. V. A., Keliat, B. A., Wardani, I. Y., \& Sulistyowati, N. M. D. (2019). Comprehensive Child and Adolescent Nursing Promoting the Mental Health of Adolescents through Cognitive Behavior Group Therapy and Family Psychoeducation Cognitive Behavior Group Therapy and Family. Comprehensive Child and 


\section{Adolescent Nursing, 42(1), 267-276. https://doi.org/10.1080/24694193.2019.15944 59}

Kementrian Kesehatan Republik Indonesia. (2014). Undang-Undang Republik Indonesia Nomor 18 Tahun 2014 Tentang Kesehatan Jiwa (p. 02).

Maghfirah, S., Sudiana, I. K., \& Widyawati, I. Y. (2015). Relaksasi Otot Progresif Terhadap Stres Psikologis dan Perilaku Perawatan Diri Pasien Diabetes Mellitus Tipe 2. In Jurnal Kesehatan Masyarakat (Vol. 10, pp. 137-146).

Rizkiya, K., PH, L., \& Susanti, Y. (2017). Pengaruh Tehnik 5 Jari Terhadap Tingkat Ansietas Klien Gangguan Fisik yang Dirawat di RSU Kendal. Jurnal Keperawatan Muhammadiyah, 1(2), 19.

Se, A., \& Anto, M. (2014). Work stress as a worldwide problem in present time, 109, 312-
316.

https://doi.org/10.1016/j.sbspro.2013.12.463

Stuart, G. W., Keliat, B. A., \& Pasaribu, J. (2016). Prinsip dan Praktik Keperawatan Kesehatan Jiwa Stuart. Singapore: Elsevier Ltd.

Videbeck, S. L. (2011). Psychiatric Mental Health Nursing (Fifth Edit). Philadelphia: Lippincott Williams \& Wilkins.

Zaccaro, Andrea, Piarulli, Andrea. Laurino, Marco. Garella,Erika.Menicucci, Danilo., Neri, Bruno.Gemignani, Angelo.2018.”How breath control can change your life: a systematic review on psycho-physiological corelattes of slow breathing: Frontiers 